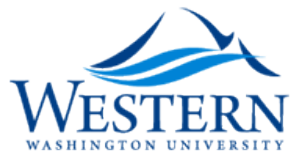

Western Washington University

Western CEDAR

$8-1993$

\title{
ODP Leg 146 Examines Fluid Flow in Cascadia Margin
}

Bernard A. Housen

Western Washington University, bernard.housen@wwu.edu

Follow this and additional works at: https://cedar.wwu.edu/geology_facpubs

Part of the Geology Commons

\section{Recommended Citation}

ODP Leg 146 Scientific Party (1993), ODP Leg 146 examines fluid flow in Cascadia margin, Eos Trans. AGU, 74(31), 345-347, doi:10.1029/93EO00459.

This Article is brought to you for free and open access by the Geology at Western CEDAR. It has been accepted for inclusion in Geology Faculty Publications by an authorized administrator of Western CEDAR. For more information, please contact westerncedar@wwu.edu. 
Eos, Vol. 74, No. 31, August 3, 1993
$\mathrm{EOS}$
T R A N S A C T I O N S.
A MERI C A N
GE O P H Y S I C A L
U N I O N

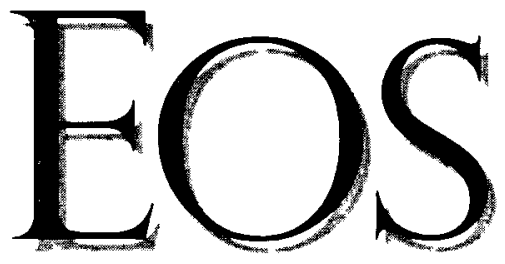

VOLUME 74, NUMBER 31

AUGUST 3, 1993

PAGES 345-352

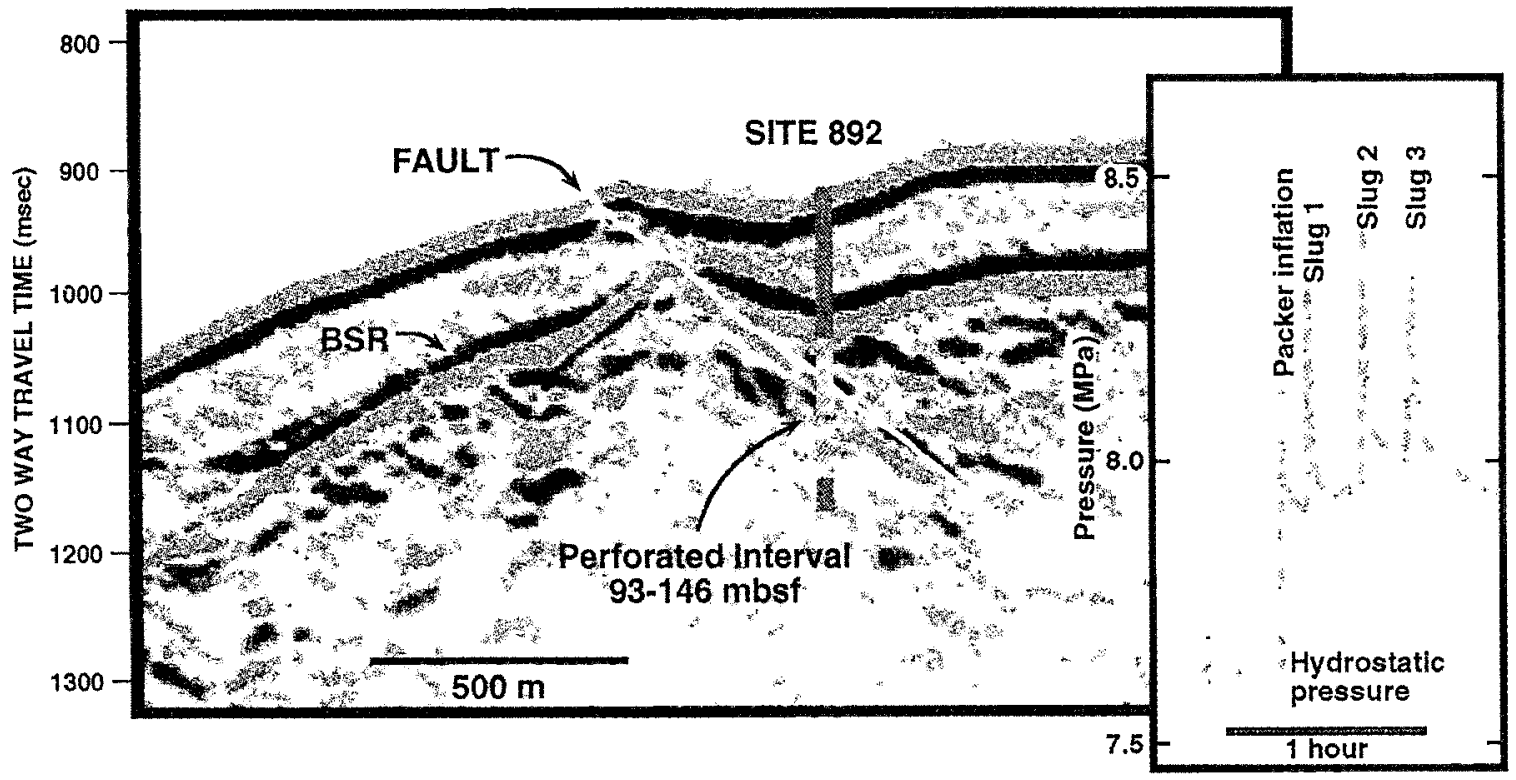

Fig. 1. A section of MCS line OR-9 showing the thrust fault (line is interpretation), the BSR (displaced toward the surface along the fault), and the position of Site 892 (which includes holes 892A to 892E). Reflections from both the BSR and the fault zone exhibit reversed polarity relative to the bottom reflector. The

inset is the raw record of the drill-string packer experiment, which tested the interval (93-146 mbsf) indicated in light green on the profile. Toriginal color image appears in the back of this volume.]

\section{ODP Leg 146 Examines Fluid Flow in Cascadia Margin \\ PAGES $345-347$}

\section{ODP Leg 146 Scientific Party}

For the better part of 2 decades, it has been known that dewatering of sediments accreted to or subducted beneath accretionary wedges is a fundamental aspect of the subduction-accretion process. Yet, evidence for fluid flow in modern accretionary wedges is largely secondary and based on the presence of geochemical and/or thermal anomalies [e.g., Vrolijk et al., 1991]; the analysis of seismic velocity as an indicator of porosity, which suggests a progressive loss of pore volume in a landward direction [e.g., Bray and Karig, 1985]; and the occurrence of sec ondary sediment microstructures characteristic of fluid movement [e.g., Maltman et al., 1992].

The only quantitative measurements of fluid expulsion at surface vents are based on submersible-deployed, seepage-meter data

Direct correspondence to Shaune Webb, Ocean Drilling Program, Science Operations, Texas A\&M Research Park, 1000 Discovery Drive, College Station, TX 77845-9547 [e.g., Carson et al., 1990], and these results - coupled with the surface area of the vents-indicate flow rates significantly greater than can be supported by steadystate dewatering [Le Pichon et al., 1992]. The fluid budgets and mass fluxes associated with accretion are poorly constrained. Results of previous drilling suggest two distinct modes of fluid flow: channelized flow along fault zones (primarily the décollement [e.g., Mascle and Moore, 1990]) or diffuse flow, which is apparently accommodated by a pervasive fracture permeability [e.g., Taira et al., 1992].

Leg 146 set out specifically to examine these two modes of fluid movement in the Cascadia continental margin, determine the hydraulic parameters (in-situ pore pressure, permeability, and specific storage) that control the flow, and provide well-constrained estimates of the fluid budget associated with deformation near the toe of the wedge. In addition, the presence of distinct bottomsimulating reflectors (BSRs) associated with the targeted subbottom flow regimes pro- vided an opportunity to test the hypotheses [see Hyndman and Davis, 1992] that relate formation of the BSR to upward fluid advection through the gas hydrate stability field.

Four locations were drilled off Vancouver Island and Oregon. Site 888 is a reference section seaward of the accretionary wedge, and Site 891 is at the toe of the wedge, where the borehole intersected the frontal thrust fault rising from the décollement. Site 889 , and a nearby subsidiary site drilled to only $50 \mathrm{~m}$ below seafloor, Site 890 , are located on the middle continental slope in an area of diffuse fluid discharge. Site 892 (Figure 1) is located on the middle continental slope on a fault known to be actively expelling fluids. Instrumented borehole seals [ $D a$ vis et al., 1992] were installed at sites 889 and 892 to isolate the holes hydraulically, record post-drilling temperature and pressure measurements, and provide fluid samples (Figure 2).

\section{Site 892}

Several of our principal objectives were realized at Site 892 , which provided unequivocal evidence for active flow along a fault zone, confirmation of the BSR as a phasechange boundary, and the unexpected occurrence of gas hydrates that apparently incorporate sulfur 2-17 m below seafloor (mbsf). The site is located in the Pliocene portion of the wedge, in water 670-m deep. The holes cut an out-of-sequence thrust fault 
(Figure 1) whose surface trace is marked by a biotherm and active fluid vents. The section at Site 892 is dominated by terrigenous silty clay with thin, interlayered sands. Layers and nodules of diagenetic carbonate are common throughout the sediment column.

Faulting is distributed throughout the section (notably at 50, 68, and 106-175 mbsf), as indicated by sediment deformation structures (shear bands, fractures, stratal disruption) in recovered core, formation microscanner (FMS) images of fractures, biostratigraphic age reversals, and bulk density/porosity discontinuities, the last apparently produced by juxtaposition of shear-compacted sediment against porous, fractured zones at 68 and 116 mbsf.

Active flow at Site 892 was demonstrated by the first successful packer test in an accretionary wedge (Figure 1). The drill-string packer was set in unperforated casing and monitored conditions integrated over the interval of perforated casing from 94-146 mbsf. Extrapolation of the pressure-decay curves indicates that in-situ pressure was 0.2 $\mathrm{MPa}$ (mega pascal) above hydrostatic. These data represent a minimum differential pressure, however, as the hole was open for 36 hours prior to the test. A post-cruise record of pressure (and temperature) recovery at Hole $892 \mathrm{~B}$ will come from the instrumented borehole seal deployed in this hole, which records temperature, pressure, and tilt hourly for a 2-year period following shut-in.

Fluid advection is also indicated by geochemical and temperature anomalies (Figure 3). Bacterial methanogenesis occurs at very shallow depths ( $<2$ mbsf) at Site 892 , but it is mixed with thermogenic hydrocarbons $\left(\mathrm{C}_{2}-\mathrm{C}_{6}\right)$ below $68 \mathrm{mbsf}$. These latter species must be advected from 1- to $4-\mathrm{km}$ depths within the wedge, as the maturity of the local kerogen is insufficient to produce them. In-situ temperature measurements define a linear temperature gradient of $51^{\circ} \mathrm{C} / \mathrm{km}$ that implies regional conductive heat transfer. Superimposed on this gradient, however, are two points with temperatures $1.6-2.5^{\circ} \mathrm{C}$ above the trend, which we attribute to local advection of more deeply sourced fluids along fault zones. The limited vertical extent of the anomalies indicates little thermal diffusion and requires very recent flow.

Downhole logs and a vertical seismic profile (VSP) at Site 892 establish that the BSR is caused by free gas below about 71 mbsf. At greater depths, borehole sonic logging velocities drop to a nearly uniform 1.5 $\mathrm{km} / \mathrm{s}$ (Figure 4), which implies that seawater in the hole has a higher velocity than the surrounding sediments and controls the short ray path of the sonic tool. Wider ranging VSP-derived velocities $(\leq 1.4 \mathrm{~km} / \mathrm{s}, 68-92$ mbsf) confirm this explanation. These low velocities indicate the presence of gas bubbles [Domenico, 1976] in the pore water below the BSR. The lack of free gas above 71 mbsf apparently reflects the stability field of gas hydrates, where methane is present only as hydrate or in solution.

Gas hydrates occur as crystals, pellets, and aggregates in near-surface (2-17 mbsf) sediments at Site 892 , presumably as a con- sequence of upward fluid advection, although clarification of the mechanisms of their formation and accumulation await additional analyses. An unusual aspect of these shallow deposits is their high concentration (up to 10,000 ppmv (parts per million by volume)) of $\mathrm{H}_{2} \mathrm{~S}$. The association of $\mathrm{H}_{2} \mathrm{~S}$ with hydrates, and its concentration at levels several orders of magnitude above equilibrium solubility values for pore water, suggest that sulfur is also present as a hydrated form. Because deeper fluids contained no $\mathrm{H}_{2} \mathrm{~S}$, we are investigating a microbial mechanism for sulfur fixation near the sediment-water interface.

\section{Sites 889 and $\mathbf{8 9 0}$}

In contrast to the focused flow encountered at Site 892, sites 889 and 890 (Figure 1) were drilled where high-angle faults of limited length and displacement characterize the structure of the accreted section. These upper Pliocene-lower Pleistocene clayey silts and sands are overconsolidated and are often broken by small-scale $(<5-\mathrm{cm}$ long, about 1 -mm wide) fractures below $128 \mathrm{mbsf}$ Drilling did not penetrate a major, throughgoing fault zone as at Site 892 . Above the accreted sediments, upper Quaternary slope and slope-basin turbidites, hemipelagites, and mass-flow deposits constitute a cap of normally consolidated, unfractured sediments. Diagenetic carbonates occur throughout the section.

A packer test at Site 889 was unsuccessful, but measurement of near-hydrostatic pressure at 140 mbsf with the LAST (lateralstress tool) II tool and a linear temperature gradient of $54^{\circ} \mathrm{C} / \mathrm{km}$ imply that fluids are not being transported rapidly. However, restriction of the sulfate-reducing zone to $0-10$ mbsf, and inorganic and organic geochemical anomalies $\left(\mathrm{Cl}, \mathrm{Ca}, \mathrm{Mg}, \mathrm{S}, \mathrm{N}, \mathrm{CH}_{4}\right.$, and $\mathrm{C}_{2} \mathrm{H}_{6}$ ) at $128 \mathrm{mbsf}$ - the slope sediment-accretionary complex unconformity-imply some advective flow. The temperature data do not preclude flow rates of a few millimeters/year, and it seems likely that Site 889 indeed represents a section dominated by diffuse fluid movement. A bore-hole seal was deployed at Site 889, and the record of pressure recovery after drilling as well as the results of active, post-cruise, draw-down tests should provide a definitive picture of the hydrogeology.

The BSR is well developed at Site 889. VSP results there, as at Site 892 , indicate that the reflection is induced by a velocity reversal due to the presence of free gas below the BSR. There is a disparity at both sites, however, between the seismically defined position of the BSR and the position of the base of the gas hydrate stability field calculated from experimentally defined data on pure water/pure methane [Katz et al., 1959] and the measured geothermal gradient. In both cases, the seismic BSR occurs at a shallower depth than would be predicted from the temperature-hydrate stability data (or at a temperature about $2^{\circ} \mathrm{C}$ less than predicted). Resolution of this disparity awaits determination of the composition of the hydrates and may require experimental determination of an

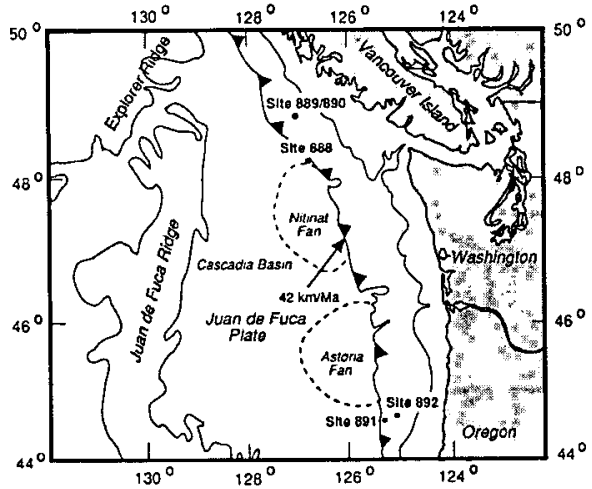

Fig. 2. The Cascadia margin convergence zone, diagrammatically indicated at the base of the continental slope, and the positions of sites drilled on Leg 146.

appropriate gas hydrate/seawater stability curve.

Massive accumulations of gas hydrate were not encountered at either Site 889 or 892. Rather, most of the hydrate appears to be finely disseminated in the pore space; macroscopic accumulations were observed only at depths less than 17 mbsf at Site 892 Temperature measurements on the cores and dilution of pore waters derived from these holes suggest that less than $10-40 \%$ of the pore space is filled with hydrate. The effect of these clathrates on the permeability structure in the wedge awaits post-cruise tests at the borehole seals.

\section{Site 891}

Site 891 was drilled to intersect the frontal thrust fault, rising from the décollement beneath the wedge that crops out on the seafloor at the base of the Oregon slope (Figure 2). We sought to determine whether fluid migration was controlled by the fault zone or by stratigraphic aquifers within the anticlinally deformed section. Although evidence for flow is unequivocal, poor core recovery at Site $891(<11 \%)$ precludes quantitative assessment of the relative importance of the two types of flow paths.

Sediments at this site consist of postmiddle-Pleistocene clayey silts and interbedded fine- to medium-grained sands, probably laid down as deep-sea fan deposits prior to incorporation into the accretionary wedge. The upper 200 mbsf appear to be normally consolidated, and geochemical processes are dominated by sulfate reduction in this section. Biogenic methane concentrations increase, between 200 and $440 \mathrm{mbsf}$, and maxima in biogenic methane alternate with maxima in hydrothermal hydrocarbons that have migrated either along fault splays or permeable sands. The presence of the olefin ethene $\left(\mathrm{C}_{2} \mathrm{H}_{4}\right)$, which is unstable, suggests that the fluid dispersal system is currently active. In addition to the organic components, the absence of $\mathrm{SO}_{4}$ and distinctly different concentrations of $\mathrm{Cl}$ and $\mathrm{Mg}$ dictate that these sediments are hydraulically isolated from the overlying section. Carbonate cementation near the boundary at $200 \mathrm{mbsf}$ may provide the barrier to fluid exchange.

There is no significant geochemical 


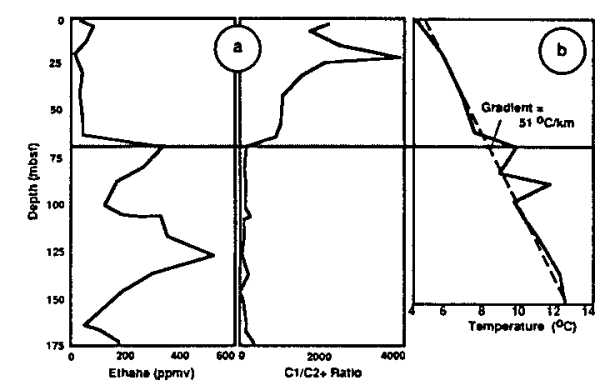

Fig. 3. (a) Organic geochemical profiles of ethane and the ratio of $C_{1}$ (methane) to higher-order hydrocarbons $\left(C_{2}-C_{6}\right)$ at Site 892. The line at $68 \mathrm{mbs} f$ denotes the top of the BSR and is coincident with a faulted in terval. (b) Temperature profile for Site 892. Dashed line represents linear gradient derived from points excluding anomalies at 68 and $88 \mathrm{mbsf}$.

anomaly, however, at $375 \mathrm{mbsf}$, the position of the frontal thrust fault on the seismic section, and the fault at this position appears not to be an active aquifer. Alternatively, the active portion of the frontal thrust may have stepped down to about $440 \mathrm{mbsf}$, for the porosity and pore-water chemistry of sediments lying below this level are distinct and place them in the footwall. Although no sediment was recovered at the inferred position of this fault, we anticipate that analysis of an oblique VSP experiment run in Hole 891C will delineate the fault's precise location.

\section{Site 888}

Site 888 in Cascadia Basin (Figure 2) was drilled $7-\mathrm{km}$ seaward of the toe of the wedge to provide a reference section for physical properties, geochemistry, and downhole geophysical studies, which will constrain future fluid-budget models. The $570-\mathrm{m}$ thick drilled section consists of upper Pleistocene to Holocene clayey silts and interbedded fine- to medium-grained sands, some of which ex-

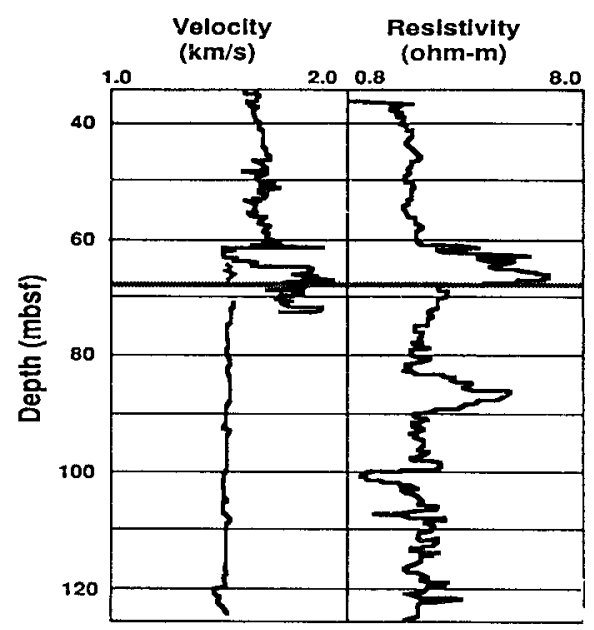

Fig. 4. Sonic velocity and resistivity logs from from Hole 892C. The line at $68 \mathrm{mbsf}$ denotes the top of the BSR. High-resistivity zones ( 66 and $86 \mathrm{mbsf}$ ) overlie zones of active flow as indicated by the temperature record (Figure 3). ceed $1 \mathrm{~m}$ in thickness. Deposition occurred on the outer to middle parts of Nitinat Fan, at rates that averaged about $1 \mathrm{~km} / \mathrm{m}$.y. As a result of the rapid deposition and the high proportion of sand below $193 \mathrm{mbsf}$, the section becomes increasingly underconsolidated at greater depths. Anomalies in porewater $\mathrm{Cl}$ concentration at 70 and 514 mbsf imply fluid flow to counteract diffusive dissipation. The flow probably originates from differential compaction of sands and silts, but we cannot rule out the possibility of fluids being transmitted from the accretionary wedge to the east, along permeable strata. An anomalous concentration of methane $(68,000 \mathrm{ppm}$ volume) occurs in a porous sand at $351 \mathrm{mbsf}$, without concomitant changes in pore-water composition. Either the methane has been generated in place, or it has migrated to its present location independent of the pore water.

\section{Long-Term Investigations}

Leg 146 has significantly augmented our knowledge of fluid flow in one modern accretionary wedge. A fuller understanding of the hydrogeology, the interaction between gas hydrate accumulation and the flow regime, the mass fluxes of both organic and inorganic chemical species, and the role of bacteria in modifying those fluxes will be gained after samples taken during the cruise and data recorded at the borehole seals at sites 889 and 892 are analyzed. The two sealed holes offer the promise of fluid samples and records of downhole temperature and pressure that are not influenced by the drilling operation, as well as the first extended hydrogeologic tests to determine insitu hydraulic parameters.

\section{ODP Leg 146 Scientific Party}

B. Carson, Lehigh University, Bethlehem, Penn. and G. K. Westbrook, University of Birmingham, Birmingham, United Kingdom, (co-chief scientists); R. J. Musgrave, Ocean Drilling Program, College Station, Tex., (staff scientist); J. Ashi, University of Tokyo, Japan; B. Baranov, Russian Academy of Sciences, Moscow; K. Brown, Scripps Institution of Oceanography, La Jolla, Calif.; A. Camerlenghi, Osservatorio of Geofisico Sperimentale, Italy; J.-P. Caulet, Laboratoire de Géologie du Muséum, Paris, France; N. Chamov, Russian Academy of Sciences, Moscow; M. B. Clennell, University of Birmingham, United Kingdom; B. Cragg, University of Bristol, United Kingdom; P. Dietrich, Institut für Geologie,
Freiberg, Germany; J.-P. Foucher, IFREMER, Cedex, France; B. Housen, University of Michigan, Ann Arbor; M. Hovland, STATOIL, Stavanger, Norway; R. Jarrard, University of Utah, Salt Lake City; M. Kastner, Scripps Institution of Oceanography, La Jolla Calif.; A. Kopf, IGL Justus-Liebig-Universitàt Giessen, Germany; M. MacKay, University of Hawaii, Honolulu; J. C. Moore, University of California, Santa Cruz; K. Moran, Bedford Institute of Oceanography, Nova Scotia, Canada; R. J. Parkes, University of Bristol, United Kingdom; J. Sample, California State University, Long Beach; T. Sato, Niigata University, Japan; E. Screaton, Lehigh University, Bethlehem, Penn.; H. Tobin, University of California, Santa Cruz; M. Whiticar, University of Victoria, British Columbia, Canada; S. Zellers, University of Texas, Austin

\section{References}

Bray, C. J., and D. E. Karig, Porosity of sediments in accretionary prisms and some implications for the dewatering process, J. Geophys. Res., 90, 768, 1985.

Carson, B., E. Suess, and J. C. Strasser, Fluid flow and mass fux determinations at vent sites on the Cascadia margin accretionary prism, J. Geophys. Res., 95, 8891, 1990.

Davis, E. E., K. Becker, T. Pettigrew, B. Carson, and R. MacDonald, CORK: A hydrologic seal and downhole observatory for deep-ocean boreholes, in Proc. Ocean Drill. Program, Initial Rep., 139, 43, College Station, Tex., 1992.

Domenico, S. N., Effect of brine-gas mixture on velocity in an unconsolidated sand reservoir. Geophysics, 41, 882, 1976.

Hyndman, R. D., and E. E. Davis, A mechanism for the formation of methane hydrate and seafloor bottom simulating reflectors by vertical fluid expulsion, J. Geophys. Res., 97, 7025, 1992.

Katz, D., D. Cornell, R. Kobayahi, F. Poettmann, J. Vary, J. Elenbass, and C. Weinaug, Handbook of Natural Gas Engineering, McGraw-Hill, New York, 1959

Le Pichon, $\mathrm{X}$., et al., Fluid venting activity within the eastern Nankai Trough accretionary wedge: A summary of the 1989 Kaiko-Nankai results, Earth Planet. Sci. Lett., 109, 303, 1992.

Maltman, A., T. Byrne, D. Karig, S. Lallament, and Leg 131 Scientific Party, Structural geological evidence from ODP Leg 131 regarding fluid flow in the Nankai prism, Japan, Earth Planet. Sci. Lett., 109, 463, 1992.

Mascle, A., and J. C. Moore, ODP Leg 110: Tectonic and hydrologic synthesis, Proc. Ocean Drill. Program Sci. Results, 110,409 , College Station, Tex., 1992.

Taira, A., et al., Sediment deformation and hydrogeology of the Nankai Trough accretionary prism: Synthesis of shipboard results of ODP Leg 131, Earth Planet. Sci. Lett., 109, 431, 1992.

Vrolijk, P., A. Fisher, and J. Gieskes, Geochemical and geothermal evidence for fluid migration in the Barbados accretionary prism, Geophys. Res. Lett., 18, 947, 1991.

\section{AGU Forms}

\section{Global Change Committee}

\section{PAGES 345-346}

AGU is creating a new committee on global environmental change, announced AGU President Ralph Cicerone. The idea was proposed by several AGU members and section officers, he said. They convinced him that AGU's efforts are needed for the science of human-accelerated environmental change to progress well. In addition, Cicerone noted that the focus on this topic will challenge and broaden AGU and many of its members.

Volunteers are encouraged to serve on this new committee. Interested AGU members should contact Cicerone, AGU Executive Director Fred Spilhaus, or AGU Director of Education and Research Gene Bierly at AGU Headquarters no later than September 15.

\section{AGU Committee on Global Environmental Change}

Definition: Global environmental change is meant to include the science of climate 